\title{
Stability Analysis of Finance System Model with Information Effect
}

\author{
Vivi Aida Fitria', Yudistira Arya Sapoetra ${ }^{2}$ \\ ${ }^{1}$ Institut Teknologi dan Bisnis Asia Malang, viviaidafitria@gmail.com \\ ${ }^{2}$ Institut Teknologi dan Bisnis Asia Malang, yuditstiraarya@gmail.com
}

doi: https://doi.org/10.15642/mantik.2020.6.1.13-19

\begin{abstract}
Abstrak: Partisipasi Indonesia dalam berinvestasi di pasar modal masih sangat rendah, salah satu penyebabnya adalah kurangnya informasi. Oleh karena penelitian ini membahas tentang analisis kestabilan pada sistem keuangan jika ditambah dengan pengaruh informasi. Terdapat dua titik keseimbangan, yaitu titik tanpa suku bunga dan indeks harga instrument keuangan serta titik eksisnya suku bunga, tingkat permintaan investasi, indeks harga dan input control pengaruh informasi. Hasil analisis kestabilan lokal kedua titik kesetimbangan tersebut adalah stabil dengan syarat tertentu. Hasil simulasi numerik pada penelitian ini menunjukkan bahwa sesuai dengan hasil analisis.
\end{abstract}

Kata kunci: Analisis Kestabilan, Sistem Keuangan, Informasi

\begin{abstract}
Indonesia's participation in investing in the capital market is still very low, one of the causes is the lack of information. So this study discusses the analysis of stability in the financial system if influenced by information. We find that the model has two equilibrium point, that are point without interest rates and the price index of financial instruments and then the existing point of interest rates, the level of investment demand, price indexes and the influence of control input the information. The results of the local stability analysis of the equilibrium points are stable with certain conditions. The analytical result are confirmed by numerical simulations.
\end{abstract}

Keywords: Stability Analysis, Finance System, Information

How to cite: V. A. Fitria and Y. A. Sapoetra, "Stability Analysis of Finance System Model with Information Effect”, JMM, vol. 6, no. 1, pp. 13-19, May 2020. 


\section{Introduction}

The financial system is a key factor of economic growth in a country. If the financial system does not function properly, it can be one of the reasons a country cannot develop. Because with a good financial system, it encourage efficient capital allocation. Capital allocation will be efficient if there is a channeling of funds from people who cannot use money productively to people who can use it productively. An efficient capital allocation is one of the causes of a stable financial system

The stability of a financial system is influenced by several factors, including interest rates, price indexes and investment demand. A three-dimensional financial system model consisting of interest rates, price indices and investment demand was introduced by Ma and Chen in 2001 [1]. Until now, researchers have continued to develop or modify financial system models. One modification is to provide input control. As done by [2], namely by adding input controls in the form of government policies which are influenced by the high and low price indexes. Therefore, this research discusses the modification of the financial system model, namely by adding input controls in the form of information about financial literacy that affects the rate of investment demand.

Based on [3], only 500,000 Indonesians become investors in the stock market. Whereas the capital market has an important role in the economic development of a country because the capital market has two functions, namely the economic function and financial function [4]. With the capital market, individual investors and business entities can channel their excess funds to invest in the capital market, and entrepreneurs can obtain additional capital funds to expand their business networks from investors in the capital market [5]. According to [6], this is due to lack of information about financial literacy. In accordance with the National Survey on Financial Literacy it shows that only 3.79\% of Indonesians understand well in the capital market. On the other hand, $93.79 \%$ are classified as ignorant about the capital market, meaning that for every 100 people, 94 do not know the capital market [3].

Therefore, the purpose of this study is to analyze the stability of the financial system model if coupled with input controls in the form of information about financial literacy that affects the rate of investment demand. According to [7], the Indonesia Stock Exchange (IDX) always provides better education aimed at increasing the number of active investors in the capital market in Indonesia, then the results of the analysis of this research are expected to provide an overview to the IDX, how the stability of the financial system model with the information variable. In addition, this research also conducted a numerical simulation of a financial system model using Matlab software

\section{Methods}

The method used in this research is literature study method, which contains theories that are relevant to research problems. The literature study method is useful for developing concepts or theories that form the basis of study in research [8]. While the stages in this study are:

a. Review and understand the continuous form of the financial system model

b. Modify the model by adding information influence

c. Analyzing the dynamic stability of a modified financial system model.

d. The numerical scheme obtained is then simulated using the MATLAB software.

e. Conclusions. 


\section{Result and Discussion}

\subsection{Model Formulation}

This section discusses modification of the financial system model by adding control input in the form of information. The financial system model that will be modified is from the model introduced by Ma and Chen in [1], namely:

$$
\begin{aligned}
& \dot{x}=(y-a) x+z \\
& \dot{y}=1-b y-x^{2} \\
& \dot{z}=-x-c z
\end{aligned}
$$

Where $\boldsymbol{x}$ is the interest rate, $\boldsymbol{y}$ is the level of investment demand, $\boldsymbol{z}$ is the price index of the financial instrument, $\boldsymbol{a}$ is the total savings in the bank, $\boldsymbol{b}$ is the investment cost, and c is the elasticity of demand. After that it was developed by [2] by adding input controls in the form of government policies. The following are the results of the modification of Saputri, et al [2] :

$$
\begin{aligned}
& \dot{x}=(y-a) x+z \\
& \dot{y}=1-b y-x^{2} \\
& \dot{z}=-x-c z+u \\
& \dot{u}=-d x y-k u-m z
\end{aligned}
$$

Where $\boldsymbol{u}$ is the input control, $\boldsymbol{d}, \boldsymbol{k}$ and $\boldsymbol{m}$ are the appropriate amplitude [9]. Furthermore, in this study the financial system model was modified by adding an input control $(\boldsymbol{u})$ in the form of the influence of information about financial literacy. This input control affects the rate of investment demand. The following are the results of modifications to the financial system model introduced by Ma and Chen:

$$
\begin{aligned}
& \dot{x}=(y-a) x+z \\
& \dot{y}=1-b y-x^{2}+u \\
& \dot{z}=-x-c z \\
& \dot{u}=\frac{k y}{1+b y}-k_{0} u .
\end{aligned}
$$

The influence function of information is introduced by [10]. The effect of information on financial literacy can increase the rate of investment demand, with is the rate of information growth and represents the saturation constant [11].

\subsection{Stability Analysis}

In this section, will determine the point of equilibrium in system (3). Then determine the stability of each equilibrium point. Analysis of the stability of the equilibrium point is done by linearizing the system (3) around each equilibrium point obtained. 
System (3) has 2 points of equilibrium, it is $E_{0}\left(0, \frac{k+\sqrt{k^{2}+4 k_{0}^{2} b^{2}}}{2 k_{0} b^{2}}, 0, \frac{k y^{*}}{k_{0}\left(1+b y^{*}\right)}\right)$ and $E_{1,2}\left( \pm \sqrt{1-a b-\frac{b}{c}+\frac{k(a c+1)}{k_{0}(c+a b c+b)}}, a+\frac{1}{c}, \pm \frac{x^{*}}{c}, \frac{k(a c+1)}{k_{0}(c+a b c+b)}\right)$ on condition of existence $a b+\frac{b}{c}-\frac{k(a c+1)}{k_{0}(c+a b c+b)} \leq 1$. From the two equilibrium points, an equilibrium analysis is carried out by first linearizing the system. To linearize system (3), a transformation must be made using perturbation theory [12], so that a Jacobian system is obtained around a fixed point:

$$
J=\left[\begin{array}{cccr}
y^{*}-a & x^{*} & 1 & 0 \\
-2 x^{*} & -b & 0 & 1 \\
-1 & 0 & -c & 0 \\
0 & \frac{k}{\left(1+b y^{*}\right)} & 0 & -k_{0}
\end{array}\right]
$$

The Jacobi matrix is then used to analyze the stability of each model's equilibrium point. Analyzing system stability (3) is done by determining the eigenvalues of matrix $\mathbf{J}$. The eigenvalues of matrix $\mathbf{J}$ are obtained by solving the equation $\boldsymbol{\operatorname { d e t }}(\boldsymbol{J}-\boldsymbol{\lambda I})=\mathbf{0}$ [13], namely :

$$
h_{0} \lambda^{4}+h_{1} \lambda^{3}+h_{2} \lambda^{2}+h_{3} \lambda+h_{4}=0
$$

with

$$
\begin{aligned}
& h_{0}=1 \\
& h_{1}=b+k_{0}+c+a-y \\
& h_{2}=1+b k_{0}+c b+c k_{0}+a b+a k_{0}-b y^{*}-k_{0} y^{*}-c y^{*}+a c+2 x^{* 2}-\frac{k}{\left(1+b y^{*}\right)^{2}} \\
& h_{3}=b+k_{0}+b c k_{0}+a b k_{0}-b k_{0} y^{*}-c b y^{*}-c k_{0} y^{*}+a b c+a c k_{0}+2 c x^{* 2}+2 k_{0} x^{* 2}-\frac{k\left(c+a-y^{*}\right)}{\left(1+b y^{*}\right)^{2}} \\
& h_{4}=b k_{0}-c b k_{0} y^{*}+a b c k_{0}+2 c k_{0} x^{* 2}+\frac{k c\left(y^{*}-a\right)-k}{\left(1+b y^{*}\right)^{2}}
\end{aligned}
$$

The equilibrium point of the autonomous system with the Jacobi matrix (4) will be stable if all the roots of equation (5) are negative or $\boldsymbol{\lambda}_{\boldsymbol{i}}<\mathbf{0}, \boldsymbol{i}=\mathbf{1}, \mathbf{2}, \ldots, \boldsymbol{n}$. The RouthHurwitz criterion can be used to determine the sign of the eigenvalues matrix (4) by using the coefficients of the equation [14]. Based on the Routh-Hurwitz Criteria, so that the eigenvalue in equation (5) is negative then it must apply $h_{4}>0$ with 


$$
\left\{\begin{array}{l}
h_{1}, h_{2}, h_{3}, h_{4}>0 \\
h_{1} h_{2}-h_{3}>0 \\
h_{1} h_{2} h_{3}-h_{3}^{2}-h_{1}^{2} h_{4}>0
\end{array}\right.
$$

If condition (6) is fulfilled, system (3) is at a $E_{0}$ and $E_{1,2}$ fixed point will be stable. However, if the opposite condition is taken $h_{1}<0$ then the system (3) will be in an unstable condition.

\subsection{Numerical Simulation}

In this section, a system solution (3) is simulated. To simulate the results of numerical analysis of models used the Runge Kutta order 4 method in MATLAB software. Here is a numerical simulation for the equilibrium point.

$E_{0}\left(0, \frac{k+\sqrt{k^{2}+4 k_{0}^{2} b^{2}}}{2 k_{0} b^{2}}, 0, \frac{k y^{*}}{k_{0}\left(1+b y^{*}\right)}\right)$. In this simulation parameters are used $a=0,9 ; b=0,8 ; c=0,5 ; k=0,0001$ and $k_{0}=0,8$, so the point of equilibrium $E_{0}$ is $(0 ; 1.25 ; 0 ; 0.00016)$. The following is Figure 1 which shows the phase portrait of the solution model (3) with initial values $(10,5,1,5)$.

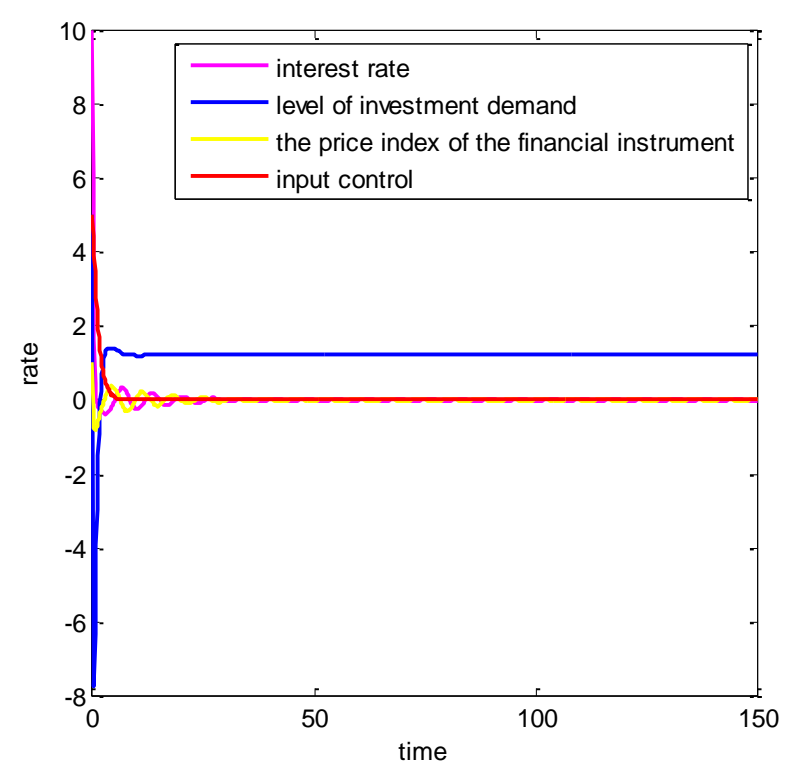

Figure 1. Graph of $E_{0}$ Stability Point

Based on Figure 1, the point $E_{0}$ is stable, shown by a graph that leads to the equilibrium point. This proves that if the level of investment demand is influenced by information even though there is no influence of interest rates and the price index of financial instruments, the financial condition is stable with certain conditions. For point $E_{1,2}\left( \pm \sqrt{1-a b-\frac{b}{c}+\frac{k(a c+1)}{k_{0}(c+a b c+b)}}, a+\frac{1}{c}, \pm \frac{x^{*}}{c}, \frac{k(a c+1)}{k_{0}(c+a b c+b)}\right) \quad$ of financial 
simulations is used $a=0,9 ; b=0,5 ; c=1,5 ; k=0,05$ and $k_{0}=0.13$ parameter values, so the point of equilibrium is $(0.745 ; 1.57 . ;-0.496 ; 0.338)$. A phase portrait of the $E_{1,2}$ equilibrium point is shown in Figure 2, with initial values $(10,5,1,5)$.

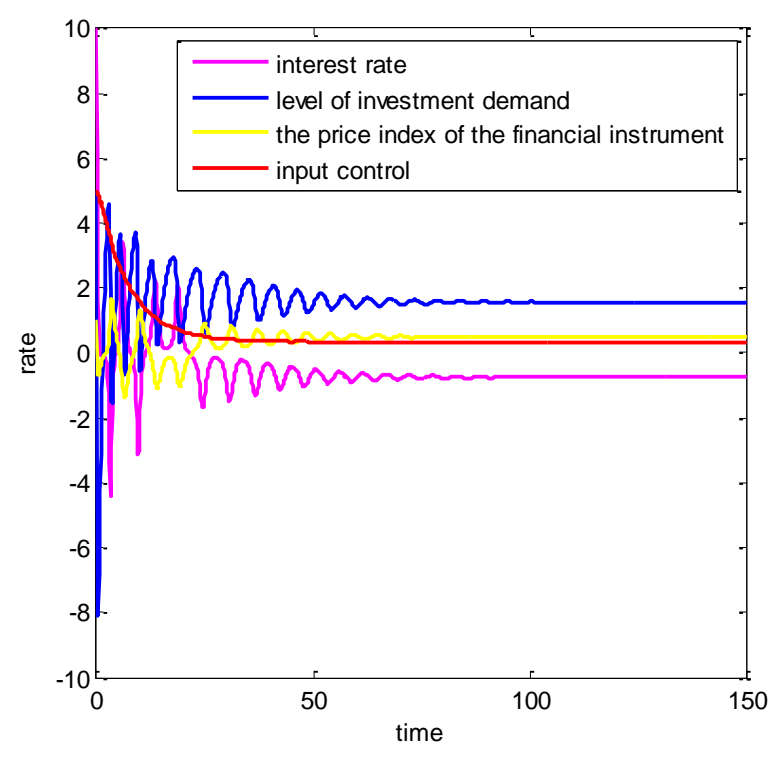

Figure 2. Graph of $E_{1,2}$ Stability Point

The graph in Figure 2 also goes to the point of equilibrium. Therefore, the point is stable with certain conditions. This proves that the financial system model that is affected by interest rates, investment demand levels, changes in financial instrument price indexes and the addition of input controls in the form of information will be stable, provided that the stability conditions of the model are met. This is in accordance with research [15] which concludes that investment knowledge has a significant positive effect on student investment interests.

\section{Conclusions}

The results of the analysis of the stability of the financial system model if coupled with input controls in the form of information about financial literacy that affects the rate of investment demand is stable, both at a $E_{0}$ fixed point and at a $E_{1,2}$ fixed point provided $h_{1}, h_{2}, h_{3}, h_{4}>0, h_{1} h_{2}-h_{3}>0$ and $h_{1} h_{2} h_{3}-h_{3}^{2}-h_{1}^{2} h_{4}>0$. Therefore, if the financial system in Indonesia adds control in the form of information about financial literacy, the condition of the financial system in Indonesia will be stable. This research can be developed by adding a delay time on certain variables. Given the conditions that cause the rate of change in the financial system has been delayed. For example, if there is a delay in the increase in interest rates in Indonesia due to the adjustment of the United States (US) interest rates, it will only be done if inflation reaches 2 percent

\section{References}

[1] A. Aram, "Dynamic Behavior of a Nonlinear Macro-financial System," York University, 2014.

[2] A. D. Saputri, H. Hariyanto, and M. S. Winarko, "Analisis Bifurkasi Hopf Pada Sistem Keuangan Dengan Kontrol Input," J. Sains dan Seni ITS, vol. 7, no. 2, 2018, 
doi: 10.12962/j23373520.v7i2.30171.

[3] G. S. Djojohadikusumo, "Indonesian National Strategy for Financial Literacy," no. 2, Jakarta: Financial Services Authority of the Republic of Indonesia, 2013.

[4] F. Muklis, "Perkembangan dan Tantangan Pasar Modal Indonesia," J. Lemb. Keuang. dan Perbank., vol. 1, no. 1, 2016.

[5] I. Yuliana, Investasi Produk Keuangan Syariah. Malang: Uin-Maliki Press, 2010.

[6] Novi Yushita Amanita, "Pentingnya Literasi Keuangan Bagi Pengelolaan Keungan Pribadi," J. Nominal, vol. VI, p. 11, 2017.

[7] D. Saputra, "Pengaruh Manfaat, Modal, Motivasi dan Edukasi Terhadap Minat Dalam Berinvestasi di Pasar Modal," Futur. J. Manaj. dan Akunt., vol. 5, no. 2, p. 178 _ 190, 2018.

[8] V. W. Sujarweni, Metodeologi Penelitian. Yogyakarta: Pustaka Baru Perss, 2014.

[9] Subiono, "Sistem Linear dan Kontrol Optimal," in 1, Surabaya: Institut Teknologi Sepuluh Nopember, 2013.

[10] A. Kumar, P. K.Srivastava, and Y. Takeuchi, "Modeling the role of information and limited optimal treatment on disease prevalence," J. Theor. Biol., vol. 414, pp. 103119, 2017.

[11] R. W. Wilda and M. A. Imron, "Sensitivity and Stability Analysis of a SEIR Epidemic Model with Information," vol. 9, no. 1, pp. 47-53, 2019.

[12] J. R. Chasnov, Mathematical Biology. Hongkong: University of Science and Technology, 2009.

[13] W. . Kelley and A.C.Peterson, The Theory of Differential Equations: Classical and Qualitative. New York: Springer, 2010.

[14] J. D. Murray, Mathematical Biology I: An Introduction Third Edition. Verlag Berlin Heidelberg: Springer, 2002.

[15] L. K. Merawati and I. P. M. J. S. Putra, "Kemampuan Pelatihan Pasar Modal Memoderasi Pengaruh Pengetahuan Investasi dan Penghasilan pada Minat Berinvestasi Mahasiswa," J. Ilm. Akunt. dan Bisnis, vol. 10, no. 2, pp. 105-118, 2015. 